\title{
Public Reform Paradoxes and the Old Effectiveness-Efficiency Problem
}

\section{Mirko Pečarič*}

\author{
UDK $\quad 35.072 .2$ \\ DOI $\quad 10.31297 /$ hkju.18.4.1 \\ Original scientific paper / izvorni znanstveni rad \\ Received / primljeno: $\quad$ 10.1.2018. \\ Accepted / prihvaćeno: $\quad$ 16.3.2018.
}

Although effectiveness and efficiency are old comrades of public administrations, they still often cause unintended consequences. The paper addresses the success/failure of reforms and the outcomes thereof. It claims the core problem of rational decision-making lies not in rationality per se, but in a lack of concept and/or insufficient attention to the behaviour of complex adaptive systems. With the help of complex adaptive systems, cybernetics, and combinations of effectiveness and efficiency, the paper presents the essential elements for adaptive (human) decision-making (such as diversity, variation, selection, adaptation, and integration), as the framework whereby unintended, reverse, and neutral effects can be reduced. New rules/decisions should be based on different levels of planning and adaptation, and on moving from the general to the more specific, in accordance with context specificity and unplanned,

* Mirko Pečarič, Associate Professor of the Faculty of Administration, University of Ljubljana, Slovenia (izvanredni profesor Fakulteta za upravu, Sveučilište u Ljubljani, Slovenija, e-mail: mirko.pecaric@fu.uni-lj.si).

ORCID ID: https://orcid.org/0000-0002-0551-5682 
emergent things. It seems the hardest thing to address is the human character that does not (want to) recognise a situation as the situation in which some things must be spotted, evaluated, and changed if needed.

Keywords: effectiveness, efficiency, complex adaptive systems, public administration, decision-making

One of the most remarkable and sorely lamented patterns of buman affairs is also one of the most obscure in origin: the culmination of action in effects directly contrary to those that were intended. (Sieber, 1981, p. 3)

\section{Introduction ${ }^{* *}$}

For Hamilton (one of the founding fathers of the USA) "the true test of a good government is its aptitude and tendency to produce a good administration" (Hamilton et al., 2008, p. 356). He also warned that "a dangerous ambition more often lurks behind the specious mask of zeal for the rights of the people than under the forbidding appearance of zeal for the firmness and efficiency of government" (Hamilton et al., 2008, p. 13). Hamilton was basically addressing the relation between effectiveness and efficiency and he was right: many wrongs have been done in the name of different isms, but the efficiency of government per se is blind and can lead to new isms. In recent decades, EU countries have begun with public reforms as "[d]eliberate changes to the structures and processes of public sector organizations with the objective of getting them (in some sense) to run better" (Pollitt \& Bouckaert, 2011, p. 2). To "run better" is a very general notion and can refer to anything that could increase goal-fulfilment or a ratio between inputs and outputs; i.e., everything that can be more effective or efficient. To be effective is "to get the right things done [while] efficiency is the ability to do things right" (Drucker, 2002, p. 2).

** This paper is based upon work supported by the Slovenian Research Agency under Grant No. J5-8238 (The development of a holistic governance model for an efficient and effective Slovenian public administration). 
With the help of this distinction, this paper will reveal some discrepancies in the practical use of these notions.

Although effectiveness and efficiency $(\mathrm{E} \& \mathrm{E})$ are old ${ }^{1}$ comrades and continually used, this paper claims that a relation between (absent) effectiveness and (overly emphasised) efficiency remains unresolved. Based on the legal documents described below and on case law, the paper will show that $\mathrm{E} \& \mathrm{E}$ are used interchangeably, and despite the presence of negative effects, it comes as a surprise that important documents still address $E \& E$ without a procedure or methodology whereby the content of these terms could be more clearly elaborated. The goal is not only to achieve a clearer meaning, but to accomplish results with the fewest possible negative effects. Alongside different management reforms, decision-makers must not lose sight of the whole: all reforms are only specific answers to inadequate earlier reforms, and it could be valuable to go one step back, to see how/why different reforms have emerged. If the big picture is not taken into account, a space for different paradoxes emerges, and, for instance, NPM was/is no exception. This paper will test the presumption(s) that the problem of rational decision-making tools may lie in:

a) a propensity to trust rational problem-solving based solely on experts' disregards for opposite effects of altruistic actions based on people's values and emotions (this factor makes experts unable to carry out predictions because their mental frameworks cannot systematically comprehend non-rational effects),

b) a lack of conceptual structure to estimate the probability of opposite effects lead to accommodating or adapting actions, and

c) unquestioned methods whereby power holders interpret or label actions as effective or efficient.

The paper will focus on understanding the differences between E\&E and equity from a systemic/cybernetic point of view because - despite continuity of use - these terms are used interchangeably, are not used in the correct sequence, or in the right pairs. There are numerous examples of texts which mention $\mathrm{E} \& \mathrm{E}$, but they do so in the context of their use, without an emphasis on their combinations and newly emerged (mostly

1 The principle of effectiveness was known as early on as Roman times in the dictum ut res magis valeat quam pereat - an interpretation that validates outweighs one that invalidates (Scalia \& Garner, 2012). Ambrogio Lorenzetti painted the Allegory and Effects of Good and Bad Government in his frescoes in the years 1337-1339. They can be viewed in the Palazzo Pubblico in Siena, Italy (Carli, 1983). 
unintended) consequences. For this purpose, a decision tree will be used to demonstrate the probability of an E\&E pair by means of the Bayes' theorem. This theorem presented by means of a decision tree will show which effects are relevant for the probability of E\&E success and what kind of unintended consequences may arise as a result of different $\mathrm{E} \& \mathrm{E}$ combinations. The latter will also be compared with the immune system to demonstrate a proper course of action and a model will be presented whereby things will be placed in "cybernetic order".

\section{Examples of Mixed Use of Effectiveness and Efficiency}

\subsection{The European Union's Understanding of Effectiveness and Efficiency}

The European Commission, e.g. in its 2001 White Paper on European Governance, proposed an enhanced dialogue with civil society, better use of expert advice, and better impact assessment to improve the quality of policy proposals. Among the five principles of good governance (openness, participation, accountability, effectiveness, and coherence) effectiveness addresses impact (as an element of efficiency) and divides the indivisible (effective policies and objectives). ${ }^{2}$ With Article 4 of the Treaty on European Union (TEU $)^{3}$ the principle of effectiveness became the prevailing guide for the future determination of authorisations underlying the functions and powers of institutions. In Article 298 Treaty on the Functioning of the European Union (TFEU) ${ }^{4}$ lays the legal ground for

${ }^{2}$ Policies must be effective and timely, delivering what is needed on the basis of clear objectives, an evaluation of future impact and, where available, of past experience. Effectiveness is used to implement EU policies in a proportionate manner and on taking decisions at the most appropriate level (European Commission, 2001).

3 The Member States shall take any appropriate measure, general or particular, to ensure fulfilment of the obligations arising out of the Treaties or resulting from the acts of the institutions of the Union. The Member States shall facilitate the achievement of the Union's tasks and refrain from any measure which could jeopardise the attainment of the Union's objectives.

${ }^{4}$ Official Journal C 326 of 26/10/2012. 
European law on good administration. ${ }^{5}$ These two legal grounds present a proper understanding of the relations between E\&E (effectiveness objectives; efficiency - the manner whereby objectives can be achieved), which is more vague in the effet utile or the principle of effectiveness (for which efficient [not effective] legal protection may sometimes be more appropriate). ${ }^{6}$ The EU Court can raise ${ }^{7}$ the effet utile of the Treaty as a whole, ${ }^{8}$ of European law (Hauer, ${ }^{9}$ Factortame $\left.{ }^{10}\right)$, of a specific policy area (Van Eycke $\left.{ }^{11}\right)$, or of a specific Treaty article $\left(\right.$ Bosman $\left.^{12}\right)$ (here it is valid to speak of effectiveness). Article 19(1) of the TEU states that "[M]ember States shall provide remedies sufficient to ensure effective legal protection in the fields covered by Union law". The right to effective judicial protection is determined in the EU by Article 47 of the Charter of Fundamental Rights of the European Union, which is a binding provision of primary law in the EU legal order; it implies an open, discretionary notion of efficiency (to facilitate the achievement of tasks and refrain from any measure which could jeopardise them) to attain effectiveness (objectives). $\mathrm{E} \& \mathrm{E}$ are mentioned in the most important legal documents of the EU; it is therefore relevant what measures may be appropriate to ensure fulfilment of obligations and what kind of facilitation may be suitable for the achievement of tasks (or abstention from measures which could jeopardise the attainment of objectives). On the other hand, the mere mention

${ }^{5}$ In carrying out their missions, the institutions, bodies, offices and agencies of the Union shall have the support of an open, efficient and independent European administration.

${ }^{6}$ The effective judicial protection obliges the EU Member State courts to ensure that national remedies and procedural rules do not render claims based on EU law impossible in practice or excessively difficult to enforce. Opinion of AG Jääskinen delivered on 7 February 2013 in Case C-536/11 Bundeswettbewerbsbehörde v Donau Chemie AG, Donauchem GmbH, DC Druck-Chemie Süd GmbH \& Co KG, Brenntag Austria Holding GmbH, Brenntag CEE GmbH, ASK Chemicals GmbH, formerly Ashland-Südchemie-Kernfest $\mathrm{GmbH}$, ASK Chemicals Austria GmbH, formerly Ashland Südchemie Hantos GmbH. Here efficiency could be better: the statement is focused not on goals, but on the difficulty of their achievement.

7 The approach was first canvassed in Case 13/77 GB-INNO-BM SA v Association des détaillants en tabac (ATAB) [1977] ECR 2115.

8 Case 2/74 Jean Reyners v Belgian State [1974] ECR 00631.

${ }^{9}$ Case 44/79 Liselotte Hauer v Land Rheinland-Pfalz [1979] ECR 03727.

10 Case C-213/89 The Queen v Secretary of State for Transport, ex parte: Factortame Ltd and others [1990] ECR I-02433.

11 Case 267/86 Pascal Van Eycke v ASPA NV [1988] ECR 4769.

12 Case C-415/93 Union royale belge des sociétés de football association $v$ Jean-Marc Bosman [1995] ECR I-04921. 
of effectiveness indicates the problem of how it is to be achieved: every word in legal acts must be considered to have effect and the previously mentioned Article 47 should also be valid without the word "effective"; ${ }^{13}$ the added word per se points to some kind of disadvantage, not to the lack of a word, but to the way in which the word should be put into practice. From the examples above it is clear that there is a need to understand the holistic unity of E\&E.

\subsection{Different Cycles of Emphasis on Efficiency at the Expense of Effectiveness and Vice Versa}

A public management reform - popular in many OECD countries during the 1980s and 1990s - known as "New Public Management" (NPM) is an example of E\&E under inclusiveness. It included efforts to reinvent ("entrepreneurial") government with a shift towards privatisation, quasi-privatisation, contracting out, and public-private partnerships, away from core government institutions with independent executive agencies to slow down or reverse government growth in public spending and staffing, with the introduction of performance measurement and results-oriented management systems, with greater responsibility and accountability for public managers, greater competition in the public sector, and the like (Cole \& Eymeri-Douzans, 2010; Hood, 1991; Osborne \& Gaebler, 1993; Pollitt \& Bouckaert, 2011). Although NPM focused on results, the reforms listed above are examples of efficiency, not of effectiveness: these reforms are for the most part techniques or procedures whereby better results can be achieved, and not results per se. NPM did not address what is right or wrong (what values people have), but solely how to be the best at doing the right or wrong things. It seems both parts should be addressed together.

It is no accident that in response to NPM other doctrines in public administration have emerged and addressed what NPM had left out: effectiveness (i.e., the right things, values). This can be seen in the new public service (serving, not steering) (Denhardt, J. V. \& Denhardt, 2011; Denhardt, R. B. et al. 2013), which places a strong emphasis on ethics and the reaffirmation of democratic values, citizenship, and service in the public interest; on the principles of good administration (Parliamentary

13 The meaning of Article 47 should be no different without the word "effective": Everyone whose rights and freedoms guaranteed by the law of the Union are violated has the right to a remedy before a tribunal in compliance with the conditions laid down in this Article. 
and Health Service Ombudsman, 2017; The Parliamentary and Health Service Ombudsman, 2009) and on good administration through a better system of administrative procedures (OECD, 1999; SIGMA, 2012). New public service also emphasizes governance as "the involvement of society in the process of governing" (Pierre \& Peters, 2000, p. 7); as governing processes that are "hybrid and multijurisdictional, linking plural stakeholders in complex networks" (Bevir, 2010, p. 3), or as the "participatory process of governing the social, economic, and political affairs of a country, state, or local community through structures and values that mirror the society [and] include the state as an enabling institution, the constitutional framework, the civil society, the private sector, and the international/ global institutional structure within limits" (Farazmand, 2004, p. 11). The Economic and Social Commission for Asia and the Pacific (UNESCAP) is a rare example which mentions $\mathrm{E} \& \mathrm{E}$, equity and inclusiveness among the principles of good governance, in addition to participation, consensus-orientation, accountability, transparency, responsiveness, and the rule of law (2009). Emphasizing only one or only the other side in different cycles always brings about shortcuts, surprises and paradoxes on both sides. This is true for NPM (Dunleavy et al. 2005; Hood \& Peters, 2004; Slyke, 2003), good governance (Dijkstra, 2013; Noore Alam \& Mohd. Zin, 2007; Velluti, 2009; Wilén, 2007), or any other reform. Decision-makers should not disregard the difference between theory and practice either: in addition to all the building blocks, i.e., theory, there is also practice, which could achieve completely different results than those stated as objectives. Theory and practice must be closely connected and the same stands for $\mathrm{E} \& \mathrm{E}$, from both a theoretical and a practical perspective.

\section{Effectiveness and Efficiency}

Tönnies previously dealt with the relationship between $\mathrm{E} \& \mathrm{E}$ in his Gemeinschaft und Gesellschaft. With a focus on the universal clash between small-scale "communities" and large-scale competitive market "societies", he drew a distinction between the traditional, emotional, supportive community as a collective, which uses natural, common law (Gemeinschaft) and the modern, rational or efficient society of rational individuals, who use statute law (Gesellschaft). He grouped both parts within the single concept of the state with a hybrid, dualistic character, which he thought was also required in public administration: "society is capable to apply a general will independently of the state $\ldots$ and the natural order deter- 
mines the position of individuals [based on which] ... the state invests mandatory authority to individuals, until in the end every person participates in the will of the state ... this idea is found to a limited extent in the system of public administration" (Tönnies, 2001, pp. 237-238). ${ }^{14}$ For Weber bureaucracy is founded on the scientific efficiency of sine ira et studio (without anger and fondness), but this kind of attitude - unlike in Tönnies - questions the very roots of our personalities: "bureaucracy ... develops the more perfectly the more the bureaucracy is "dehumanized", the more completely it succeeds in eliminating from official business love, hatred, and all purely personal, irrational, and emotional elements which escape calculation" (Weber, 1946, pp. 215-216). This is usually called the Weberian paradox or "the irony of scientific efficiency improving our lifestyle while simultaneously undermining our meaning systems and emotional security" (Parrillo, 2005, p. 502). While Tönnies understood E\&E in a more holistic manner within the state and society as a single unit, Weber's paradox can be seen as NPM's forefather.

The quality of public administration can be understood as the trinity that addresses efficiency as the ratio of maximising results vis-ã-vis the resources used, effectiveness as the ratio of results gained to those planned, and equity. Why should equity be added? Not solely because it is one of the principles of good governance; the main reason lies in its connection to both efficiency and effectiveness. One part of the whole is effectiveness as a necessary condition to achieve efficiency, while the other is equity as a starting point which gives the mental framework of perspectives based on a mix of courage, emotions, and reason. ${ }^{15} \mathrm{~A}$ mixture of those three gives preferences or social needs (wanted as direct outputs [results] or

14 Tönnies' concepts were also used by Weber, albeit with different, more fluid notions of communal Vergeminsschaftung that is based on a subjective feeling of people who belong together, while Vergesellschaftung is based on associative relationships that rest on rationally motivated adjustments of interests that may be "affectual or traditional" (Weber, 1978, pp. 40-41).

15 This trinity constitutes Plato's parts of the soul as a (good/bad) combination of thymos, eros and nous (Plato, 1976). Equity is needed as a ground/parametre/predisposition or as a mental framework whereby E\&E are evaluated. Equity was emphasised in the 1970s by the so-called New Public Administration, whose theory emerged from the subsequent meetings of the Minnowbrook Conference (Frederickson, 1989; Frederickson et al., 2012; Waldo \& Miller, 2006), most notably from the social equity argument: "laws and regulations are often ineffective guides for administrators trying to determine what to do. However trite this observation may seem, laws and regulations are better at telling administrators what not to do than what to do ... Social equity values have to do with the fairness of the organization, its management, and its delivery of public services. Social equity asks these questions: For whom is the organization well managed? For whom is the organization efficient? For whom 
more indirect outcomes [effects]), also known as effectiveness. Efficiency without effectiveness is almost meaningless; it is more essential to do the right things (effectiveness) than to do the wrong things in the right way. Despite this intuitively correct inference, there is more: as is the case whenever there are two elements, there are four combinations, and to fully describe $E \& E$ their combinations should be stated. If every form of the administration of society is "about activity - how people act and how they might act more effectively and more justly" (Bevir, 2010, p. 11), it is relevant to know how to act in the proposed way. Effectiveness and efficiency are closely linked and could be synonyms for quality and outcome. They must be addressed within the same framework: because there are four combinations for every two parts, this also holds true for E\&E. ${ }^{16}$

Decision-makers cannot create more efficient plans to anticipate future changes (because efficiency depends on effectiveness); they must apply decision-making techniques with relevant sensors or indicators of change in the actual framework of space and time and in the appropriate order ${ }^{17}$ to first accommodate effectiveness based on equity. Key decision-makers in public administration must ensure a way to communicate the final results and measurable impacts of the performance of public administration to the people, because it is only the people who can provide the decision-makers with relevant/democratic weights or ponders on the importance of a goal (regardless of the fact that a different weight is attached to the same goal in other countries). What is therefore effective in one country is irrelevant for another, as long as these countries do not have common frameworks (e.g. as do the member countries of the EU, OECD, or ECHR). If these elementary conditions had been built into New Public Management, there would have probably been fewer reverse or unintended effects. And here is where the paradox lies: despite the power that is vested in the people, not only do public administrations more or less do their work without public opinion or community profiling, they mostly do not even anticipate the unintended consequences of their decisions.

is the organization economical? For whom are public services more or less fairly delivered?" (Frederickson, 2010, pp. 14, 15).

16 A good decision and a good outcome; a good decision and a bad outcome; a bad decision and a good outcome; and a bad decision and a bad outcome.

17 For Drucker, an effective executive makes decisions as part of a systematic process with clearly defined elements and a distinct sequence of steps (1. classifying the problem; 2 . defining the problem; 3 . specifying the answer to the problem; 4. deciding what is "right" rather than what is acceptable; 5 . incorporating into the decision the action to carry it out; 6 . testing the validity and effectiveness of the decision against the actual course of events) (1967). 


\section{Unintended Consequences of E\&E Relations}

Well-intentioned actions almost always (also) produce unwanted effects. In ancient Greece, the temple of Apollo at Delphi bore the inscriptions gnotbi seauton (know thyself), meden agan (nothing in excess), and, according to Plutarch, a large letter "E" (1936). While Plutarch gives seven possible explanations, ${ }^{18}$ we would like to believe it is meant to represent the five human senses (which render human beings human in the first place, or as Delphi might say: "you are"), whereby humans can help themselves reason "if" something can be done (in this manner the letter "E" could also stand for effectiveness, efficiency, and equity). It could be said that ancient Greek remedies for unwanted effects were impartiality, moderation, and action, whereby humans use all their senses and/or abilities to achieve goals. In all forms of complex adaptive systems (CAS) negative/positive (neutral) effects are present due to emergence as the characteristic element of CAS: "[a]n emergent property is a global behaviour or structure which appears through interactions of a collection of elements, with no global controller responsible for the behaviour or organization of these elements. The idea of emergence is not reducible to the properties of the elements" (Feltz et al., 2006, p. 241). The whole is not only more than the sum of its parts, but what "the whole" is or could be cannot be known in advance; it only emerges through interaction, by emergent combinations that rise exponentially with a greater number of parts or relations: two elements (e.g. effectiveness and efficiency) yield four combinations (like in any other combination of $n^{r}$ or $2^{2}$ ), four elements result in sixteen combinations, and so on. This is very similar to the butterfly effect, where tiny causes can have significant effects (Lorenz, 1963).

If decision-makers could agree with the idea of emergence at a general/organisational level, this results in a "surprise" for decision-making: problems do not only pre-exist before their solutions/decisions, but also emerge spontaneously in the course of multiple relations as problem-solv-

18 (1) It was dedicated by the Wise Men, as a protest against interlopers, to show that their number was actually five and not seven ( $E I=E$, five). (2) EI is the second vowel, the Sun is the second planet, and Apollo is associated with the Sun (EI = E, the vowel). (3) EI means "if": people ask the oracle IF they shall succeed, or IF they shall do this or that (EI = "if"). (4) EI is used in wishes or prayers to the Apollo (EI = "if" or "if only"). (5) EI, "if", is an indispensable word in logic for the construction of a syllogism (EI = "if"). (6) Five is the most important number in mathematics, physiology, philosophy, and music (EI = E, "five"). (7) EI means "thou art" and is the address of the consultant to the god, to indicate that the god has eternal being (EI = "thou art") (Plutarch, 1936, pp. 194-195). 
ing occurs. This means that $\mathrm{E} \& \mathrm{E}$ relations and combinations must be constantly re-evaluated due to new differences/preferences that did not exist before. This insight into the theory of CAS, along with "unmovable", rational, maximised-utility decisions, also speaks for the Stanford School of Decision Analysis: for Holzman "a good decision analysis helps the agent decide what to do in part by forcing the agents to reconsider what they want to get out of the situation they find themselves in. This might mean actively creating preferences that didn't exist before, re-evaluating what one wants in life" (Kaplan, 2012, p. 439). The traditional understanding of rational decision-making is at odds with Kaplan's view that "it is our actions in the world themselves that are primary, and our reflections and discourse about them should often be thought of more as ways of rationalizing and explaining them than as ways of actually making decisions" (Kaplan, 2012, p. 440). Although many decision-makers would rather opt for pre-existent, rational decision-making than for instant decision-making, the fact remains the people and institutions continually change through interaction, as does our decision-making.

Merton is well-known for his unintended consequences of action, which he divides into three types: " 1 . those which are functional for a designated system, and these comprise the latent [those that are neither intended nor recognized] functions; 2 . those which are dysfunctional for a designated system, and these comprise the latent dysfunctions; and 3. those which are irrelevant to the system which they affect neither functionally nor dysfunctionally" (Merton, 1968). Variations, adaptations, (dys)functions, and tensions offer an analytical focus within the study of dynamics and operative changes during regulation and implementation, and motivate us to find a way whereby these elements would not disrupt adaptive stability within its normal limits. His less well-known remedy for these elements/ consequences is functional analysis, based on the interpretation of data through their consequences (the latter are based on sustained theoretical clarification and cumulative empirical research, in which the description is not limited solely to the concept of performance in a researched field but also includes a systematic account of the people participating and the onlookers, of the types and rates of interaction among the performers and the audience, and of changes in these patterns of interaction in the course of the interpretation of the process) (Merton, 1968) ${ }^{19}$. His focus

19 The descriptive protocol of this kind of analysis should, so far as possible, include: 1) location of participants in the pattern within the social structure-differential participation; 2) consideration of alternative modes of behaviour excluded by emphasis on the ob- 
on the evaluation of consequences (seeing/understanding an organisation through the function it performs) places Merton squarely in the centre of our E\&E debate. Each case or action has multiple (good, bad, semi-good/ bad, or neutral) consequences, present on different levels. These trigger an evaluation problem of the best, worst, and average consequences, which becomes all the more important in the salus populi domain. The notion of emergence described earlier could explain Merton's observation that "activities oriented toward certain values release processes which so react as to change the very scale of values which precipitated them" (Merton, 1936, p. 903), or the very process of prediction effects the process predicted (the self-fulfilling prophecy). It is therefore highly relevant how predictions are made to (dis)enable system adaptations (or Merton's [dys]functions).

Merton's unwanted consequences and/or social disorganisation describe difficulties that are not fully contrary to intended/purposive actions, but focus mainly on side effects: "[t]he composite of faults in the normative and relational structure of a social system described as social disorganization can be thought of as inadequacies in meeting one or more of the functional requirements of the system" (Merton, 1961, p. 720). Maybe this functionalistic focus pre-empted other elements that might not only have a stake in unintended effects, but amplify them: one is the more elaborated role of human agency, ${ }^{20}$ the second is the role of control and communications in systems, the third is the role of the system's innate properties (adaptation, emergence, relations, exponential growth, and other social systems) and the fourth is that "consensus is not society-wide; it is local ... each separate social unit maintains not the whole society, but its own special needs ... and these special interests often conflict" (Parrillo, 2005, p. 16). Sieber enumerates seven mechanisms that convert an agent's intentions into the opposite (not the less important) ones: "functional disruption, exploitation, goal displacement, provocation, classification, over commitment, and placation. These mechanisms should not be

served pattern (i.e., attention not only to what occurs but also to what is neglected by virtue of the existing pattern); 3) the emotive and cognitive meanings attached by participants to the pattern; 4) a distinction between the motivations for participating in the pattern and the objective behaviour involved in the pattern; 5) regularities of behaviour not recognized by participants but which are nonetheless associated with the central pattern of behaviour (Merton, 1968).

20 This variable includes rationalisation of conduct, self-monitoring, goal setting, and a host of private motives for action, the relationship of which the system requirements seem highly tenuous in the functionalist scheme (Sieber, 1981, p. 32). 
thought of as exhaustive nor ... do I have any illusion that the last word has been uttered on the dynamics whereby each mechanism produces reverse effects" (Sieber, 1981, p. 56). There is no space in this paper to describe all unintended consequences, but the fact remains that when one talks about emerging unintended consequences, self-precaution is always needed: each intervention can cause a new one or represent a change for the old ones. Each recommendation can be only a proposal/hypothesis that requires further experimentation and/or investigation. Despite the difficulties described, one very general note can be made: all CAS are of evolutionary nature in which variation, differentiation, selection, and integration represent building blocks; these should be built into all systems of (non-technical) human decision-making, because humans themselves are CAS. With these limitations and/or predispositions, in the following section a general system of E\&E relations will be put forward as a guide to what could be relevant on the path of decision-making.

\section{The Best Way to Predict the Future is to Create It}

In order to create a system of future scenarios, the basic elements of cybernetics will be used because it is (currently) the best branch for investigating regulatory systems: their constructions, restrictions, and potentials. ${ }^{21}$ Cybernetics or control and communication in the animal and the machine (Wiener, 1961) starts with any scanning process that increases the quantity of data and performs individual processes with a high degree of accuracy. Large amounts of data require a processing system. The elements below also try to follow this approach.

\subsection{Functional Prerequisites for the Effectively-Efficient System of Public Goals}

Numerical processing. Humans and societies are CAS and in studying such systems, "we follow what happens to the information" (Gell-Mann, 2002,

21 Why it is so under-used in the field of the interdisciplinary public administration, which in practice it regulates the most, is another question. 
p. 23). Numerical processing is needed 22 because a CAS "discovers regularities in its incoming data stream by noticing that parts of the stream have features in common ... As time goes on, more and more frozen accidents, operating in conjunction with the fundamental laws, have produced regularities. Hence, complex systems of higher and higher complexity tend to emerge with the passage of time through self-organization" (Gell-Mann, 2002, pp. 370, 371). Self-organisation is one of the basic elements of a CAS, which tends to progress towards a state of equilibrium (Ashby, 1960; Foester, 1960; Gershenson \& Heylighen, 2003). For Ashby, another cybernetician, "a system is any set of associate variables, measured as a measurable quantity which at every instant has definite numerical value. The power of control is established when the experimenter can force a variable to take any prescribed series of values" (Ashby, 1960). As regards numerical processing, Dennet explains "human consciousness $\ldots$ in terms of the operations of a virtual machine, a sort of evolved (and evolving) computer program that shapes the activities of the brain" (Dennet, 2012, p. 509), while to Pinker "[t]he mind is a system of organs of computation, designed by natural selection ... The mind is what the brain does; specifically, the brain processes information, and thinking is a kind of computation" (Pinker, 1997, p. 21). Discovered regularities through (mental) computation are later transferred into decisions or "patterns of a higher order" (Beer, 1966, p. 7). The task is therefore to present a human being's subconscious, computing mind more vividly.

Numerical processing and Bayes theorem. Numerical processing can be performed with the use of Bayes theorem (Ayres \& Nalebuff, 2015; Carrier, 2012; Edwards et al., 2007; Finkelstein \& Fairley, 1970; Howard, 1965) as one of the clearest mathematical examples whereby a computation of belief and/or evidence can be carried out; it is the rule that can support people with all our mathematical fallacies, ${ }^{23}$ and/or our bounded ration-

${ }^{22}$ For Wiener (the founder of the field of cybernetics) there are five requirements to accomplishing this: a computing machine should be numerical; switching devices should depend on electronic tubes; the scale of two for addition and multiplication (rather than the scale of ten) should be used; the entire sequence of operations should be laid out on the machine itself; and the machine should contain an apparatus for the storage of data which should administrate them quickly (Wiener, 1961, p. 4). The more we can measure, quantify, establish genuine fact, demonstrate what follows and what does not follow, and calculate chance and risk, the less vulnerable need the ultimate decision be (Beer, 1966, p. 10).

23 One of the most common errors is the neglect of the base rate (Kahneman, 2013; Tversky \& Kahneman, 1974). This neglect focuses only on a new specific piece of information, while ignoring the general view, and can lead to large exaggerations in the probability 
ality (Simon, 1983; Simon, 1997). This theorem is a technique of decision-making based on the determination of higher or lower probability in cases of uncertainty; it tells us how our hypotheses and logical premises can be more probable. Bayes theorem identifies how beliefs should be updated based on available evidence, and if there is no evidence, how probabilities are distributed between basic alternatives. There is no space in this paper to discuss this theorem in full, but it is easily presented by means of a decision tree: an event which on the evidence is more likely to have occurred $(\mathrm{a} \times \mathrm{b})$ is assessed in terms of percentage; the same is done for an event which based on the evidence is less likely to have happened $\left(c^{*} d\right)$, and from this the probability of $p$ is calculated: $a^{*} b / a^{*} b+c^{*} d$. Calculation using Bayes theorem predisposes the existence of a system on which information is gathered and in which changes/trends are spotted, and based on which a decision-maker can decide on future actions. ${ }^{24}$

Communication. Directly connected with (conditional) probability is communication, i.e., the role which probability plays in the generation of a message. For Shannon and Weaver (as "the fathers of information theory") "the communication system is governed by probabilities which are not independent, but ... depend upon the preceding choices" (Shannon $\&$ Weaver, 1964, p. 11). They distinguish between information and meaning, but today meaning might more appropriately be named information, while information might be called data. With this correction, the word data (not information) "in communication theory relates not so much to what you do say, as to what you could say. The amount of data is ... to be measured by the logarithm [to the base 2] of the number of available choices ... the data [not information], when there are only two choices, is proportional to the logarithm of 2 to the base 2. That is a two-choice situation characterized by data of unity, called "bit" (Shannon \& Weaver, 1964, pp. 9-10). There is always an opposite side, and what you could say is closely connected with what others (might) say, or "an effective decision is always a judgment based on "dissenting opinions" rather than a "consensus on the facts" "(Drucker, 2002, p. 24).

of an event. If we want to express our decisions more rationally, we can use Bayes theorem, which is immune to this fallacy.

${ }^{24}$ If a state discovers that in some areas a population has a $35 \%$ overall presence of some characteristic that is especially evident by $15 \%$ of people, and that $3 \%$ of people do not show this characteristic, this means that - although intuitively different, smaller prediction - a person who shows (only) signs of this characteristic has more than $73 \%$ probability of presence of this characteristic. 
System relations within ultrastability. Within this large framework of inputs and outputs, three building blocks of systems can be distinguished: the first (technical), which addresses the collection and transmission of data (through sensory inputs); the second (semantical), which transforms data into meaning and/or what can be understood/extracted/classified from data as relevant (facts); and the third (effective), which addresses goals based on the understanding of data. For the successful administration of the system's component parts and relations, Ashby's Law of Requisite Variety could be helpful; it informs us that only variety can destroy variety, ${ }^{25}$ i.e., to deal appropriately with diverse problems we need a similar number of responses, which are (at least) as distinctive as the problems expressed. Only variable, adaptive systems can deal with variety. An adaptable organism is steered by data from the environment; the organism controls its internal essential variables so they will stay within their normal/physiological limits (homeostasis) by the external administration of the environment, so that the environment will act on the variables appropriately. Ashby speaks of the principle of ultrastability (which is basically the same as efficiency (first) and effectiveness (second)):

The organism that can adapt has a motor output to the environment and two feedback loops. The first loop gives the organism non-affective information about the world around it, while the second carries information about whether the essential variables are driven outside the normal limits or not and acts on the (external) parameters. The first feedback loop plays its part within each reaction; the second determines which reaction shall occur (Ashby, 1960, pp. 82-84).

Feedback and combinations. A system affects the environment and vice versa: such a system has feedback. When decisions are made based on this (first) feedback, we are talking about the second feedback (back to the environment). The system is the whole composite of the organism and its environment; ${ }^{26}$ some property of the system belongs to the whole, to their combinations. A variable not included in the system is called a parameter and if the same reasoning is applied, a change of parameter value will also change the stability of the system in some way (in human reasoning this

25 "If the variety of the outcomes is to be reduced to some assigned number ... variety must be increased to at least the appropriate minimum. Only variety ... can force down the variety of the outcomes." (Ashby, 1957, p. 206).

26 "An important feature of a system's stability is that it is a property of the whole system ... it cannot be related to the parts considered separately ... and implies some coordination of the actions between the parts." (Ashby, 1960, p. 57). 
part is played by our predispositions from which we draw inferences). The ability to be sensitive and adaptive are as much human characteristics as societal ones and always indicate some kind of coordination.

The first two characteristics - as any other notion - are established not by content per se, but by relations they have with other processes. A human being is not a self-sufficient system that receives inputs from the senses and discharges them into actions; his or her characteristic activities can only be explained as multiple circular processes, emerging from the environment into the senses, from where they then go directly - intuitively ${ }^{27}$ and emotionally (Goleman, 1996) - or indirectly (as inputs combined with or changed by reason) back to the environment.

Summation of functional prerequisites. The system, data, information, (numerical and/or mental) processing, and self-adaptation based on requisite variety are the building blocks of all CASs. They are also reflected in the immune system (IS), as our host defence system that encompasses numerous biological structures and processes in an organism that protects us against disease. The IS can be divided into the innate and the adaptive IS. If a pathogen breaches an external barrier, the innate IS provides an immediate but non-specific response. If pathogens evade the innate response, the adaptive IS is activated and adapts its reactions during an infection to improve its recognition of the pathogen. This improved reaction is then retained after the elimination of pathogen (an immunological memory) and allows the adaptive IS to mount faster and stronger attacks each time this pathogen is encountered (Restifo \& Gattinoni, 2013). The elements of IS are similar to the effectiveness (general) and efficiency (adaptive, specific) combinations, or to the structural components of societies, ${ }^{28}$ where values (such as our parameters and predispositions) are

27 Kahneman (2013) distinguishes between System 1 (based on intuition) and System 2 (based on reason).

28 Four structural categories - values, norms, collectivities, and roles - may be related to our general functional paradigm. Values take primacy in the pattern maintenance functioning of a social system. Norms are primarily integrative; they regulate a great variety of processes that contribute to the implementation of pattern value commitments. The primary functioning of collectivity concerns actual goal attainment on behalf of the social system. Where individuals perform societally important functions, it is in their capacity as collective members. Finally, the primary function of the role in the social system is adaptive. This is particularly clear for the category of service, as the capacity to fulfil valued role performances is the most basic generalised adaptive resource of any society, though it must be coordinated with cultural, organic, and physical resources. Any concrete structural unit of a social system is always a combination of all four components (Parsons, 1966, p. 19). 
our "first line of defence", norms are the general response, and collectives and roles are the intra-social and boundary-adaptive responses to harmful circumstances. The above-mentioned cybernetic elements (adaptation; communication in the technical, semantical, and effective sense; information; numerical processing; probability; requisite variety; and ultrastability) should also be reflected in the E\&E framework of the actions of public administration. This is where another paradox lies: why are the elements of CAS familiar but not used in legislation that is primarily focused on the regulation of CAS (of which people are a representative element)?

\subsection{Requisite Variety of Scenarios in Human Complex (Not Yet) Adaptive Decision-Making Systems}

It is not superfluous to point out that all CASs are deterministic, i.e., descriptive and understandable, and because of their high sensitivity to conditions, they are also unpredictable: their effects cannot be determined precisely in advance, but nevertheless the basic frameworks within which they operate can be given. One of the first authors to use the cybernetic point of view ${ }^{29}$ vis-ã-vis unintended consequences was Parsons (1966). For him the seedbeds for the advancement of adaptive capacity are the process of differentiation, adaptive upgrading, integration, value generalisation, and inclusion. Subsequent authors who used the cybernetic point of view in their dealings with paradoxes are Margetts et al. (Margetts et al., 2012). They took Ashby's idea of requisite variety (where the homeostatic loop of a regulator's amplifiers [from the regulator to the system] and filters [from the system to the regulator] is inserted to deal solely with an interested part of the environment) and Douglas' grid-group cultural theory (Douglas, 1982, 2012). For them, success in modernisation depends on requisite variety or on a balance between the three strategies of modernisation: integration (interconnectedness, standardisation, central con-

${ }^{29}$ A society is a type of social system which attains the highest level of self-sufficiency as a system in relation to its environments. The self-sufficiency of the system is a function of the balanced combination of fixed controls over its relations with five environments [Ultimate Reality, Cultural Systems, Personality Systems, Behavioural Organisms, and the Physical-Organic Environment] and of its own state of internal integration. We have referred to a hierarchy of control which organises the interrelations of analytically distinguished systems. This includes the cybernetic aspect of control whereby systems high in information but low in energy regulate our systems higher in energy but lower in information (Parsons, 1966, p. 9). 
trol, and formal rules), economic rationalism (intensification, economic efficiency) and specialisation (scientific advancement, expert knowledge, technological development, and quantification) and counterbalance from the elementary forms of social organisation - on the hierarchy and individualism (that both sustain the three modernisation strategies they in turn tend to cultivate), but also on enclaved and isolated orderings (Margetts et al., 2012, pp. 224-227).

Their balance could be placed within the E\&E framework, which will be presented below (see Figure). The point is, because effectiveness means doing the right things, and efficiency doing things right, these terms can also be replaced with other notions like justice and fairness, common and individual, centralisation and decentralisation, integration and disintegration, values and norms, natural and technical, planning and adaptation, i.e., basically anything that could progress from the abstract towards the more specific and vice versa. More than naming, it is relevant to understand the changing nature of the environment in its measured/relevant parameters that give data/content to our notions. Here, Campbell's law can help: "the more any quantitative social indicator is used for social decision-making, the more subject it will be to corruption pressures and the more apt it will be to distort and corrupt the social processes it is intended to monitor" (Campbell, 1979, p. 85). Similar to this law is Goodhart's law: "[a]ny observed statistical regularity will tend to collapse once pressure is placed upon it for control purposes" (Goodhart, 1981, p. 111). No indicator per se is the holy grail of success and each fails if too much pressure is placed upon it (remember meden agan); not all positive and negative effects can be predicted, and the different, multiple and changing sensory units come to the fore all the more if thresholds conditions are set for different scenarios. Planning is the next stage after data has been gathered, analysed and evaluated. Although the future cannot be predicted in full, it can be invented and reflected in different scenarios.

We know what we (do not) want now (what we do not want is even more relevant, because negative consequences are present) and when the future comes, attention has to be paid to threshold conditions that require different actions planned in advance. Based on what we do not know, we can build the technical, semantical, and effective part of a governance system, in which probabilities can be calculated to predict government results, where amplifiers and filters administrate environment variety (from the general to the specific, no matter how these are named) and sense as many relations as possible to store them and predict future doings with the help of a public that should participate in things which are publicly 
relevant. Thus the problem of ex ante or ex post "emergent findings" of arguments for accepted decisions can be minimised, because a more numerous (but independent and variable) group of people can provide more relevant results than any expert can do alone (Lamberson \& Page, 2012; Page, 2008, 2010; Surowiecki, 2005). Without these elements, different unintended effects emerge more easily within E\&E. The figure below helps us to understand the combinations and unwanted consequences between $\mathrm{E} \& \mathrm{E}$, and has intentionally been left without indicators of any kind (e.g. the Effectiveness Index or the International Civil Service Effectiveness Index), because the focus should be on the framework within which $\mathrm{E} \& \mathrm{E}$ relations constantly emerge, evolve, and change in different contexts. Our focus should be on all processes whereby negative effects can be uncovered (not just on certain indicators like policy-making, procurement, or IT, whilst leaving others unattended) to design social systems that incorporate these features that have to be constantly evaluated and changed if needed. Even if some rankings of countries can be provided, this cannot be an unquestioned recipe for the changes needed. ${ }^{30}$ This can be put more simply as "stay awake at work and be alert to changes" (Figure 1).

In Figure $1 \mathrm{E} \& \mathrm{E}$ combinations and their effects are vividly presented in the form of a decision tree, which is the same one as is used for the calculation of subjective (Bayesian) probability. From the decision tree intended and harmful effects are seen to be more relevant than unintended and neutral ones, due to the absence of an active, reasoning human component in the latter pair (and indirect consent with unpleasant but unwanted, although expected effects). Looking at the decision tree, the reader can see the form of a pyramid on the right, where intended effects appear on its peak (the right side of the decision tree represents a mirror image of the four known combinations with all unknown-unknowns in their background). Results are in time (through energetic, clashing opinions and actions) reflected in values as primary units, which (re)form different perspectives. Sensory units with threshold conditions and different

${ }^{30}$ For instance, according to the Rule of Law Index 2015, Ranking of Happiness 2015, and Life Satisfaction 2016 Index, Denmark is third-/first-/third-ranking state in the world (Helliwell et al., 2016; Kaufmann \& Kraay, 2015; OECD, 2016), while according to the International Civil Service Effectiveness Index (Blavatnik School of Government \& Institute for Government, 2017) its civil service is only in the $11^{\text {th }}$ place. Would you rather have a state with a better legal environment, happier and more satisfied citizens, or a more effective civil service? And how can civil service be so ineffective as to be associated with one of the best legal environments and the happiest state in the world? Unity is more about a matter of perspective than about an index. 
Figure 1: Effects of Effectiveness-Efficiency Relations

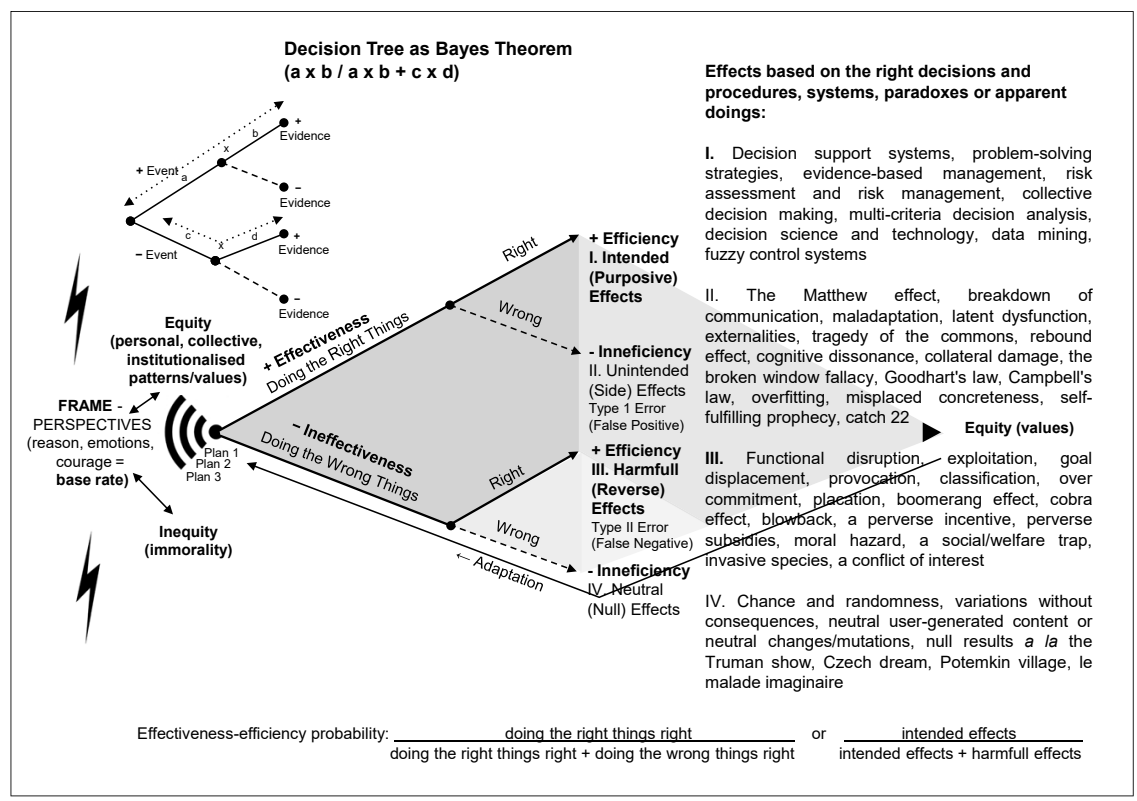

Source: author's own construction

scenarios (made by planning) are presented as the "Wi-Fi symbol" (they can also address the future from the present time). All these elements are building blocks for different perspectives whence actions emerge and constantly return through a regulatory loop to be repeated and adapted in a continuous flow of change. It seems the style of control and command regulation is no longer a valid description for many things that happen in our mental, technological, and psychological frameworks.

\section{Conclusion}

In the present time, a time of self-driving cars, it is all the more surprising that countries do not use adaptable management systems (it seems this is more of a human ${ }^{31}$ than a technical problem). Governments must recognise/create opportunities to improve the quality of the public sector (the

31 Already for Hamilton "danger to the rights of the people ... is more commonly the fault of the head than of the heart" (Hamilton et. al., 2008, p. 13). 
paradox here may lie in general consent with the last sentence, but with an absence of real actions). ${ }^{32}$ Simplification of organisational and procedural structures and processes, an increased use of IT, better regulation tools, impact assessments, optimisations of information flow, and the like should be placed within a new conceptual framework. This framework should include real time-space data sensors, and methods for data evaluation as well as for the extraction of meaning and for activating the appropriate means of achieving planned goals. This should be repeated in an endless cycle, but it simply cannot be done within the classical command and control regulation. Despite all known indicators and indexes, they always measure something outside their range; therefore, there should be a real awareness of an individual always being part of a larger whole, of two individuals exponentially forming a larger number of combinations, and of relations spontaneously causing new relations and new characteristics. The classical, rational decision-making is in the "efficiency camp", while values and principles are in the effectiveness one, but they should be always intertwined, adapted to contexts of their use and evaluated through equity. Rationality per se is deaf and values are blind; the former must always be counterbalanced by the latter (the specific by the general and vice versa). Between science and people's lives there is a kind of irony: solutions are often known but not implemented, while implementation is often carried out for the sake of implementing something. The problem of rational decision-making tools (presented in the introduction) lies in all three components: in rationality, in the lack of a conceptual structure, and in insufficient attention to the ways whereby privileges are retained (many times, this is done with the help of banal and incorrect E\&E wording). Despite advances in science, people are still going hungry in the face of an abundance of food, there are the gas and oil pipelines in poor countries with no parallel water pipelines, and so on. The last (almost unfair) sentence was not meant to "attack" the reader's conscience, but to demonstrate (by means of another paradox of immediate awareness vis-ã-vis distant actions) that (natural) science without values is merely technical, focused on efficiency, while effectiveness (social science) is weak without the right technical means. They should not only form deterministic unity

32 There is no direct connection between what people say they do, and how they actually act. In the TV series Mind Field (Season 2 - "The Greater Good") the famous "trolley problem" was tested. Unsuspecting subjects were - in the world's first realistic simulation of this moral dilemma - forced to make a life-or-death decision. Only two out of seven de facto pulled the lever to divert the train from one to another track, and thus save the lives of five but be directly responsible for one person's death. 
in Heraclitus' change and flow, but convince us they are the American $e$ pluribus unum (out of many, one) and the European in varietate concordia (united in diversity) at the same time. And the last paradox: if regulators know all this, why do they not use it? Otherwise, we will all lose it.

\section{References}

Ashby, W. R. (1960). Design for a brain: The origin of adaptive behaviour. London, United Kingdom: Chapman and Hall, https://doi.org/10.1037/11592-000

Ashby, W. R. (1957). An introduction to cybernetics. London, United Kingdom: Chapman and Hall.

Ayres, I., \& Nalebuff, B. (2015). The rule of probabilities: A practical approach for applying Bayes' rule to the analysis of DNA evidence. Stanford Law Review, 67(6), 1447-1476.

Beer, S. (1966). Decision and control: The meaning of operational research and management cybernetics. Chichester, United Kingdom: John Wiley \& Sons.

Bevir, M. (Ed.). (2010). The SAGE Handbook of Governance. London, United Kingdom: Sage.

Blavatnik School of Government \& Institute for Government. (2017). The international civil service effectiveness (InCiSE) index project. Retrieved from: https:// www.instituteforgovernment.org.uk/sites/default/files/publications/International-civil-service-effectiveness-index-July-17.pdf

Campbell, D. T. (1979). Assessing the impact of planned social change. Evaluation and Program Planning, 2(1), 67-90. https://doi.org/10.1016/01497189(79)90048-X

Carli, E. (1983). Sienese painting. New York, NY: Frederick Muller.

Carrier, R. (2012). Proving bistory: Bayes's theorem and the quest for the bistorical Jesus. Amherst, NY: Prometheus Books.

Cole, A., \& Eymeri-Douzans, J.-M. (2010). Introduction: Administrative reforms and mergers in Europe: Research questions and empirical challenges. International Review of Administrative Sciences, 76(3), 395-406. https://doi. org/10.1177/0020852310373881

Denhardt, J. V., \& Denhardt, R. B. (2011). The new public service: Serving, not steering (3rd. ed.). Armonk, NY: Routledge.

Denhardt, R. B., Denhardt, J. V., \& Blanc, T. A. (2013). Public administration (7th. ed.). Boston, MA: Wadsworth Publishing.

Dennet, D. C. (2012). Pojasnjena zavest. [Consciousness explained]. Ljubljana, Slovenia: Krtina.

Dijkstra, G. (2013). Paradoxes around good governance [Inaugural lecture]. Retrieved from https://repub.eur.nl/pub/39219/metis_186511.pdf

Douglas, M. (1982). Essays in the sociology of perception. London, United Kingdom: Routledge \& Kegan Paul. 
Douglas, M. (2012). A bistory of grid and group cultural theory [Lecture]. Retrieved from http://projects.chass.utoronto.ca/semiotics/cyber/douglas1.pdf

Drucker, P. F. (1967). The effective decision. Retrieved from https://hbr.org/1967/01/ the-effective-decision

Drucker, P. F. (2002). The effective executive. New York, NY: HarperCollins.

Dunleavy, P., Margetts, H., Bastow, S., \& Tinkler, J. (2005). New public management is dead: Long live digital-era governance. Journal of Public Administration Research and Theory. 15(3), pp. 467-494. https://doi.org/10.1093/jopart/ mui057

Edwards, W., Jr, R. F. M., \& von Winterfeldt, D. (2007). Advances in decision analysis: From foundations to applications. New York, NY: Cambridge University Press, https://doi.org/10.1017/CBO9780511611308

European Commission. (2001). European governance - White paper COM(2001)428 final. Retrieved from: https://ec.europa.eu/europeaid/european-governance-white-paper_en

Farazmand, A. (2004). Sound governance: Policy and administrative innovations. Westport, CT: Praeger.

Feltz, B., Crommelinck, M., \& Goujon, P. (2006). Self-organization and emergence in life sciences. Dordrecht, Netherlands: Springer Science \& Business Media, https://doi.org/10.1007/1-4020-3917-4

Finkelstein, M. O., \& Fairley, W. B. (1970). A Bayesian approach to identification evidence. Harvard Law Review, 83(3), 489-517, https://doi. org/10.2307/1339656

Foester, H. (1960). On self-organizing systems and their environment. In M. C. Yovits \& S. Cameron (Eds.), Self-organizing systems (pp. 31-50). London, United Kingdom: Pergamon Press.

Frederickson, H. G. (1989). Introduction. Public Administration Review, 49(2), 95-100. https://doi.org/10.2307/977327

Frederickson, H. G. (2010). Social equity and public administration. New York, NY: M.E. Sharpe.

Frederickson, H. G., Smith, K. B., Larimer, C. W., \& Licari, M. J. (2012). The public administration theory primer. Boulder, CO: Westview Press.

Gell-Mann, M. (2002). The quark and the jaguar (8th. ed.). New York, NY: W.H. Freeman \& Company.

Gershenson, C., \& Heylighen, F. (2003). When can we call a system self-organizing? In J. Ziegler, T. Christaller, P. Dittrich, \& J. T. Kim (Eds.), Advances in artificial life (pp. 606-614). Berlin, Germany: Springer Berlin Heidelberg, https://doi.org/10.1007/978-3-540-39432-7_65

Goleman, D. (1996). Emotional intelligence: Why it can matter more than IQ. New York, United Kingdom: Bloomsbury Publishing.

Goodhart, C. (1981). Problems of monetary management: The U.K. experience. In A. S. Courakis (Ed.), Inflation, depression and economic policy in the West (pp. 111-146). London, United Kingdom: Mansell Publishing. 
Hamilton, A., Madison, J., \& Jay, J. (2008). The federalist papers. (L. Goldman, Ed.). Oxford, United Kingdom: Oxford University Press.

Helliwell, J., Layard, R., \& Sachs (Eds.). (2016). World Happiness Report 2016, Update (Vol. I). New York, NY: Sustainable Development Solutions Network.

Hood, C. (1991). A public management for all seasons? Public Administration, 69(1), 3-19. https://doi.org/10.1111/j.1467-9299.1991.tb00779.x

Hood, C., \& Peters, G. (2004). The middle aging of New Public Management: Into the age of paradox? Journal of Public Administration Research and Theory, 14(3), 267-282.

Howard, R. A. (1965). Bayesian decision models for system engineering. IEEE Transactions on Systems Science and Cybernetics, 1(1), 36-40. https://doi. org/10.1109/TSSC. 1965.300058

Kahneman, D. (2013). Thinking, fast and slow. New York, NY: Farrar, Straus and Giroux.

Kaplan, J. M. (2012). Rational decision making: Descriptive, prescriptive, or explanatory? In A. Nelson (Ed.), A Companion to Rationalism. Oxford, United Kingdom: John Wiley \& Sons.

Kaufmann, D., \& Kraay, A. (2015). The worldwide governance indicators: Methodology and analytical issues. Retrieved from http://info.worldbank.org/governance/ wgi/index.aspx\#home

Lamberson, P. J., \& Page, S. E. (2012). Optimal forecasting groups. Management Science, 58(4), 805-810, https://doi.org/10.1287/mnsc.1110.1441

Lorenz, E.N.(1963). Deterministic nonperiodicflow.JournaloftheAtmosphericSciences, 20(2), 130-141. https://doi.org/10.1175/1520-0469(1963)020<0130:DN$\mathrm{F}>2.0 . \mathrm{CO} ; 2$

Margetts, H., 6, P., \& Hood, C. (2012). Paradoxes of modernization: Unintended consequences of public policy reform. Oxford, United Kingdom: Oxford University Press.

Merton, R. K. (1936). The Unanticipated consequences of purposive social action. American Sociological Review, 1(6), 894-904, https://doi.org/10.2307/2084615

Merton, R. K. (1961). Social problems and sociological theory. In R. Nisbet \& R. K. Merton (Eds.), Contemporary social problems (pp. 697-737). New York, NY: Harcourt, Brace \& World.

Merton, R. K. (1968). Social theory and social structure. New York, NY: Free Press.

Noore Alam, S., \& Mohd. Zin, M. (2007). Paradox of public sector reforms in Malaysia: A good governance perspective. Public Administration Quarterly, 31(3/4), 284-312.

Organisation for Economic Cooperation and Development (OECD) (1999). European principles for public administration, SIGMA Papers, No. 27. Retrieved from: http://unpan1.un.org/intradoc/groups/public/documents/nispacee/unpan006804.pdf.

Organisation for Economic Cooperation and Development (OECD) (2016). Better life index. Retrieved from http://www.oecdbetterlifeindex.org/topics/ life-satisfaction/ 
Osborne, D., \& Gaebler, T. (1993). Reinventing government: How the entrepreneurial spirit is transforming the public sector. New York, NY: Plume.

Page, S. E. (2008). The difference: How the power of diversity creates better groups, firms, schools, and societies. Princeton, NJ: Princeton University Press.

Page, S. E. (2010). Diversity and complexity. Princeton, NJ: Princeton University Press.

Parliamentary and Health Service Ombudsman (2017). Principles of good administration [Brochure]. Retrieved from: https://www.ombudsman.org.uk/sites/ default/files/page/0188-Principles-of-Good-Administration-bookletweb.pdf.

Parrillo, V. N. (2005). Contemporary social problems (6th. ed). Boston, MA: Allyn and Bacon.

Parsons, T. (1966). Societies: Evolutionary and comparative perspectives. Upper Saddle River, NJ: Prentice-Hall.

Pierre, J., \& Peters, B. G. (2000). Governance, politics and the state. New York, NY: Palgrave Macmillan.

Pinker, S. (1997). How the mind works. London, United Kingdom: Penguin Books.

Plato (1976). The republic. (J. Košar, Trans.). Ljubljana, Slovenia: Državna založba Slovenije.

Plutarch (1936). Plutarch: Moralia, Volume V: Isis and Osiris. The E at Delphi. The Oracles at Delphi No Longer Given in Verse. The Obsolescence of Oracles. (F. C. Babbitt, Trans.). Cambridge, MA: Harvard University Press.

Pollitt, C., \& Bouckaert, G. (2011). Public management reform: A comparative analysis: New Public Management, governance, and the Neo-Weberian state (3rd. ed.). Oxford, United Kingdom: Oxford University Press.

Restifo, N. P., \& Gattinoni, L. (2013). Lineage relationship of effector and memory T cells. Current Opinion in Immunology, 25(5), 556-563. https://doi. org/10.1016/j.coi.2013.09.003

Scalia, A., \& Garner, B. A. (2012). Reading law: The interpretation of legal texts. St. Paul, MN: West.

Shannon, C. E., \& Weaver, W. (1964). The mathematical theory of communication. Urbana, IL: University of Illinois Press.

Sieber, S. (1981). Fatal remedies: The ironies of social intervention. New York, NY: Plenum Press, https://doi.org/10.1007/978-1-4684-7456-5

Simon, H. (1983). Reason in buman affairs. Stanford, CA: Stanford University Press.

Simon, H. A. (1997). Administrative behavior (4th. ed.). New York, NY: Free Press.

Slyke, D. M. (2003). The mythology of privatization in contracting for social services. Public Administration Review, 63(3), 296-315, https://doi. org/10.1111/1540-6210.00291

Support for Improvement in Governance and Management (SIGMA) (2012). Good administration through a better system of administrative procedures. Retrieved from http://www.sigmaweb.org/publications/Comments_LawAdminProceduresKosovo_JN_Oct2012_Eng\%20\%20.pdf 
Surowiecki, J. (2005). The wisdom of crowds. New York, NY: Anchor.

The Parliamentary and Health Service Ombudsman (2009). Principles of good administration [Brochure]. London, United Kingdom: The Parliamentary and Health Service Ombudsman.

Tönnies, F. (2001). Community and civil society. (J. Harris, Ed., J. Harris \& M. Hollis, Trans.). New York, NY: Cambridge University Press.

Tversky, A., \& Kahneman, D. (1974). Judgment under uncertainty: Heuristics and biases. Science, 185(4157), 1124-1131. https://doi.org/10.1126/science. 185.4157.1124

The Economic and Social Commission for Asia and the Pacific (UNESCAP) (2009). What is good governance? [Brochure] Retrieved from http://www.unescap.org/resources/what-good-governance

Velluti, S. (2009). Experimental forms of new governance and the paradoxes of European legal integration. Lincoln, United Kingdom: University of Lincoln.

Waldo, D., \& Miller, H. T. (2006). The administrative state: A study of the political theory of American public administration. New Brunswick, NJ: Transaction Publishers.

Weber, M. (1946). From Max Weber: Essays in sociology. (H. H. Gerth \& C. W. Mills, Trans.). New York, NY: Oxford University Press.

Weber, M. (1978). Economy and society: An outline of interpretive sociology. (G. Roth \& C. Wittich, Eds.). Berkeley, CA: University of California Press.

Wiener, N. (1961). Cybernetics or control and communication in the animal and the machine. Cambridge, United Kingdom: MIT Press.

Wilén, N. (2007, March). Paradoxes or strategies in international governance: The case of Kosovo. Paper presented at the REGIMEN Conference, Mons, Belgium. Retrieved from https://repository.uantwerpen.be/docman/irua/cbf2d4/1a86b087.pdf

\section{European Court of Justice}

Case 2/74 Jean Reyners v Belgian State [1974] ECR 00631.

Case 44/79 Liselotte Hauer v Land Rheinland-Pfalz [1979] ECR 03727.

Case C-213/89 The Queen v Secretary of State for Transport, ex parte: Factortame Ltd and others [1990] ECR I-02433.

Case 267/86 Pascal Van Eycke v ASPA NV [1988] ECR 4769.

Case C-415/93 Union royale belge des sociétés de football association v JeanMarc Bosman [1995] ECR I-04921 


\section{PUBLIC REFORM PARADOXES AND THE OLD EFFECTIVENESS- EFFICIENCY PROBLEM}

\section{Summary}

Although effectiveness and efficiency are old comrades of public administrations, they still often cause unintended consequences. The relation between (absent) effectiveness and (overly emphasised) efficiency remains unresolved. The paper shows that effectiveness and efficiency are still used interchangeably, and despite the presence of negative effects, it comes as a surprise that important documents still address these terms without procedure or methodology to provide the content whereby they could be more clearly elaborated. Not only is the goal to achieve clearer meaning, but to accomplish results with the fewest possible negative effects. Alongside different management reforms, decision-makers must not lose sight of the whole; all reforms are only specific answers to inadequate previous ones, and it could be valuable to take a step back to see bow/why different reforms emerge. The paper addresses the success/failure of reforms and the outcomes thereof. It claims the core problem of rational decision-making lies not in rationality per se, but in a lack of concept and/or insufficient attention to the behaviour of complex adaptive systems. With the help of complex adaptive systems, cybernetics, and combinations of effectiveness and efficiency, the paper presents the essential elements for adaptive (buman) decision-making (such as diversity, variation, selection, adaptation, and integration) as the framework whereby unintended, reverse, and neutral effects can be reduced. New rules/decisions should be based on different levels of planning and adaptation, and on moving from the general to the more specific, in accordance with context specificity and unplanned, emergent things. It seems the hardest thing to address is the buman character that does not (want to) recognise a situation as the situation in which some things must be spotted, evaluated, and changed if needed.

Keywords: effectiveness, efficiency, complex-adaptive systems, public administration, decision-making 


\title{
PARADOKSI JAVNIH REFORMI I POZNATI PROBLEM EFEKTIVNOSTI I EFIKASNOSTI
}

\begin{abstract}
Sažetak
Pojmovi efektivnosti $i$ efikasnosti već dugo su poznati javnoj upravi, no ipak često dovode do neplaniranib posljedica. Odnos izmedu efektivnosti (koja izostaje) $i$ efikasnosti (kojoj se pripisuje prevelika pažnja) ostaje neriješen. Ta se dva pojma i dalje upotrebljavaju kao istoznačnice, te sobzirom na negativne učinke čudi da se u važnim dokumentima $i$ dalje navode bez procedure ili metodologije unutar kojih bi njihovo značenje bilo lakše pojasniti. Cilj nije isključivo pojasniti značenje, već ostvariti rezultate uz što manje negativnih učinaka. Kod provedbe reformi upravljanja donositelj odluka ne smije izgubiti širu sliku, a to je da su sve reforme specifični odgovori na neuspjele prošle reforme, te da korak unatrag može biti koristan i pokazati kako reforme nastaju. Rad se bavi (ne) uspjesima reformi i njihovim rezultatima. Autor drži da glavni problem racionalnog odlučivanja ne leži u samoj racionalnosti već u nedostatku koncepta i/ili u nedovoljnoj pažnji kada se radi o ponašanju kompleksnib adaptivnib sustava. Uz pomoć kompleksnib adaptivnib sustava, kibernetike i različitib kombinacija efektivnosti $i$ efikasnosti u radu su predstavljeni temeljni elementi adaptivnog (kod ljudi) donošenja odluka (kao što su raznovrsnost, varijacija, selekcija, adaptacija $i$ integracija). Oni čine okvir kojim se neplanirani, suprotni i neutralni učinci mogu ublažiti. Nova pravila $i$ odluke treba zasnovati na različitim razinama planiranja $i$ prilagodbe, te na pomaku od općenitog prema odredenom, u skladu sa specifičnošću konteksta i neplaniranim pojavama u nastanku. Čini se da je pritom najteže ubvatiti se u ukoštac s ljudskom prirodom, koja ne prepoznaje (ili ne želi prepoznati) bilo koju situaciju kao onu u kojoj nešto treba zamijetiti, evaluirati $i$ po potrebi provesti promjene.

Ključne riječi: efektivnost, efikasnost, kompleksni adaptivni sustavi, javna uprava, donošenje odluka
\end{abstract}

